\title{
Aye Corona! \\ The contagion effects of being named Corona during the COVID-19 pandemic
}

\author{
Shaen Corbet ${ }^{a, b *}$, Yang (Greg) $\mathrm{Hou}^{b}$, Yang $\mathrm{Hu}^{b}$, Brian Lucey ${ }^{c, d, e}$, Les Oxley ${ }^{b}$ \\ ${ }^{a}$ DCU Business School, Dublin City University, Dublin 9, Ireland \\ ${ }^{b}$ School of Accounting, Finance and Economics, University of Waikato, New Zealand \\ ${ }^{c}$ Trinity Business School, Trinity College Dublin, Dublin 2, Ireland \\ ${ }^{d}$ Institute of Business Research, University of Economics Ho Chi Minh City, Ho Chi Minh City, Vietnam \\ e University of Sydney Business School, Sydney, New South Wales, Australia
}

\begin{abstract}
In the midst of the 2020 global COVID-19 pandemic and subsequent financial market collapse, corporate entities have to navigate a number of truly unforeseen contagion risks. However, one such group included those who shared their corporate identity with aspects of the rapidly evolving coronavirus. Our results indicate the existence of sharp, dynamic and new correlations between companies related to the term 'corona', outside of pre-existing interrelationships. We provide a number of observations as to why this situation occurred.
\end{abstract}

Keywords: COVID-19; Coronavirus; Contagion; Stock Market; Sentiment.

\section{Introduction}

In late 2019, rumours had begun to persist from China that a new virus had started to spread, generating what had been described as symptoms of 'severe pneumonia' which led to an exceptional rate of fatality amongst the elderly and most vulnerable in society. In Q1 2020, through the timeline described in Table 1, COVID-19 (named after "COrona VIrus Disease, 2019") had escalated from a a small marketplace in Wuhan, China, to cause the international social distancing and home isolation of over 1 billion people worldwide, with enormous social, political and economic repercussions to follow (Goodell [2020], Sharif et al. [2020]). The dislocating effects on the economy were expected to be unprecedented since the 1920's depression Baldwin and di Mauro [2020]. However, in the middle of this chaos, an abnormality began to manifest. Brands that shared the same name with aspects of the 'coronavirus' began to report abnormal losses and sustained periods of trading volatility. While financial market conditions had deteriorated quite extensively, some companies were experiencing 
added pressures simply because their name or product base had in some way contained the term 'corona'. This research sets out to establish how this pressure manifested.

While not exclusive to pandemics, there has been some evidence of similar naming abnormalities. A classic in this genre is the renaming of companies to take advantage of the dot.com boom, documented in Cooper et al. [2001]. Benos and Jochec [2013] found evidence that US companies whose names contain the words "America" or "USA" earn positive abnormal returns of about $6 \%$ per annum during World War II, the Korean War, and recent Middle East conflicts. Kot [2011] investigated similar response in Hong Kong, Biktimirov and Durrani [2017] in Canada, Mase [2009] for companies in the UK and Kadapakkam and Misra [2007] found evidence supporting significant declines in trading volume and prices on dates when tickers were changed for companies. Kashmiri and Mahajan [2014] analysed as to whether pricing abnormalities existed for entities that were founded on historical found family ties. Whereas, Cooper et al. [2005] investigated the dynamics of this behaviour in falling markets, Cooper et al. [2005] identified changing dynamics of flows in the markets for mutual funds. In recent works, Jain and Jain [2019] and Sharma et al. [2020] analysed the pricing effects of companies adding the term blockchain to their names. Head et al. [2009] investigates the salience issue further, from the perspective of memorable stock tickers yielding excess returns, further reinforced by Xing et al. [2016]. In recent years, naming effects have also been identified to have influential when considering the addition of the terms 'blockchain' and 'cryptocurrency' into the corporate identity of the company, or through the addition of highly speculative cryptocurrency projects (Corbet et al. [2020]).

\section{Data and Methodology}

We investigate if there is evidence of a connection between the onset of the COVID-19 pandemic and any negative effects on companies with similarities in identity with the virus. To begin we conducted a thorough search using both Thomson Reuters Eikon and Bloomberg to search for all corporate entities, with active, liquid listed shares and market capitalisation values above $\$ 10$ million as of February 2020 where Corona was a substantial component of business or the business name. The results are presented in Table 2, with evidence of the associated share price behaviour and volatility presented in Figure 1. We can observe in the shaded regions of these graphs quite a strong variation in share price performance, with Constellation Brands, as owner and importer of the beer brand, Corona in the United States (STZ) and Corona Corp (5909.JP) presenting evidence of sharp declines during the pandemic period, while Coronation Fund Managers (CML), a South African company, presenting evidence of a fall in share price, but noticeably less than the other analysed companies. However, visual inspection presents evidence of sharp, elevated and sustained pricing volatility for both STZ and CML in comparison to that of 5909.JP.

In this study, we use hourly, and for robustness, daily returns to analyse the dynamic correlations between companies unfortunate to share their name with 'corona' and a range of financial assets 
including Chinese financial markets, denoted as the epicentre of the COVID-19 pandemic, the Dow Jones Industrial Average as a measure of international financial performance (Ekinci et al. [2019]), gold as a measure of the international flight to safety (Akyildirim et al. [2020]) and Bitcoin, which has presented evidence of inverse correlations with some international stock exchanges, thereby providing strong diversification benefits (Akhtaruzzaman et al. [2019], Akyildirim et al. [2019]). Our hourly returns are calculated as:

$$
r_{t, h}=\left(\ln r_{t, h}-\ln r_{t, h-1}\right) \mathrm{x} 100
$$

where $r_{t, m}$ is the return for hour $h$ on trading day $t$. Time periods with no trading activity are determined to be best represented by the last traded price. Hourly data 11 March 2019 to 10 March 2020 (5,701 observations), where the period denoted as both pre- and post-COVID-19 pandemic (4,580 and 1,122 observations respectively) is denoted to be before and after 31 December 2019. Data is sourced through Thomson Reuters Eikon. Evidence of sharp declines are evident in the period thereafter through exceptionally changes evident in the minima, skewness and kurtosis of these short-term returns. The summary statistics of the selected variables are presented in Table 3. Times are adjusted to Greenwich Mean Time to allow for comparability across the selected geographical regions. For the purpose of exchange comparison out-of-session, daily returns are used to measure dynamic correlations (similarly to the methods used by Akyildirim et al. [2019], Katsiampa et al. [2019a,b]). The time period also allows us to disaggreagate the effects of the coronavirus pandemic from the generalised equity market rout that was occasioned by the widespread arrival of the virus to the USA and European countries (on Feb 27 new cases outside China exceeded those within China for the first time, as presented in Figure 2) and the "oil price war" which began on 9-10 March. The changing correlations between the identified companies susceptible to the 'corona' naming shock and these financial assets are presented in Table 4. Comparing the periods both before and after the COVID-19 pandemic for each of our selected companies. In the case of each analysed company, there is evidence of sharp elevated positive correlations between each and the selected analysed assets. However, for companies such as Constellation Brands Inc, the owner of the beer branded Corona, while possessing a correlation of 0.032 and 0.025 respectively with both of the Shanghai and Shenzhen stock exchanges, both correlations increase sharply to 0.286 and 0.315 respectively. All companies, investigated present evidence of sharp elevations in correlation, however, this interaction between STZ, CML and Asian markets is particularly interesting as domestic correlations do not follow the same trend. This evidence suggests a sharp decoupling of the market performance of each company with their domestic exchange with simultaneous evidence of interactions where none existed before.

To specifically analyse the dynamic correlations between the corporate entities exposed to reputational exposure due to naming similarity from the COVID-19 pandemic, we employ a standard 
GARCH $(1,1)$ methodology of Bollerslev [1986] and extract dynamic conditional correlations (of Engle [2002]) that takes the form:

$$
\begin{gathered}
r_{t}=\alpha_{t}+\sum_{j=1}^{t} \sigma r_{t-j}+\sum_{j=1}^{t} \eta b_{t-j}+\sum_{j=1}^{t} \gamma v_{t-j}+u_{t} \\
\sigma_{t}^{2}=\alpha_{0}+\alpha_{1} \varepsilon_{t-1}^{2}+\beta_{1} \sigma_{t-1}^{2}
\end{gathered}
$$

where $r_{t}, e_{t}$ and $h_{t}$ are the returns of the investigated lagged corporate returns, international exchanges (Shanghai SE, Shenzhen SE and DJIA) and hedging alternatives (WTI, gold and BTC) at time $t$ respectively. $\sigma, \eta$ and $\gamma$ represent the effects of lagged returns of each selected variable on the returns of the company's hourly price volatility. The variance equation includes the long-term average volatility $\alpha_{0}$. Similar methodological structures were utilised by Corbet et al. [2015] and Corbet et al. [2020]. We explore the dynamic co-movements via the dynamic conditional correlations of Engle [2002]. The GARCH $(1,1)$ specification requires that in the conditional variance equation, parameters $\alpha_{0}, \alpha_{1}$ and $\beta$ should be positive for a non-negativity condition and the sum of $\alpha_{1}$ and $\beta$ should be less than one to secure the covariance stationarity of the conditional variance. Moreover, the sum of the coefficients $\alpha_{1}$ and $\beta$ must be less than or equal to unity for stability to hold. The GARCH $(1,1)$ methodology used in this study has the following form:

$$
\begin{gathered}
R_{t}=a_{0}+\sum_{j=1}^{3} b_{j} R_{t-j}+b_{2} S g_{t}+b_{3} S z_{t}+b_{4} D J I A_{t}+b_{5} W T I_{t}+b_{6} G_{t}+b_{7} B T C_{t}+D_{t}+\varepsilon_{t} \\
\varepsilon_{t} \mid \Omega_{t} \sim i . i . d . \quad N\left(0, h_{t}\right) \\
h_{t}=\omega+\alpha_{1} h_{t-1}+\beta_{1} u_{t-1}^{2}+\sum_{i=1}^{10} D_{C O V I D}
\end{gathered}
$$

$R_{t-j}$ represents the lagged value of the selected companies, $j$ number of hourly periods before $R_{t}$ is observed. $b_{2} S g_{t}$ represents the interaction between the selected company and the Shanghai Stock Exchange, while $b_{3} S z_{t}$ and $b_{4} D J I A_{t}$ represents the interactions with the Shenzhen Stock Exchange and DJIA respectively. Finally, $b_{5} W T I_{t}, b_{6} G_{t}$ and $b_{7} B T C$ represent the relationship between the selected companies and the returns of WTI, gold and Bitcoin respectively. $D_{t}$ and $\sum_{i=1}^{t} D_{v}$ are included in both the mean and variance equations to provide estimates of the corporate pricing 
and volatility estimates relating directly to the COVID-19 pandemic. Bollerslev [1986] argued for restrictions on the parameters for positivity, $\omega>0, \alpha \geq 0$ and $\beta \geq 0$, and the wide-sense stationarity condition, $\alpha+\beta<1$. While the GARCH $(1,1)$ process is uniquely stationary if $E\left[\log \left(\beta+\alpha \epsilon_{t}^{2}\right)\right]<0$, Bollerslev [1986] also proved that if the fourth order moment exists, then the model can handle leptokurtosis. Bonferroni adjusted results are presented in this analysis. To cater the multiple hypothesis problem, we adjust the significance level using the Bonferroni correction, which leads to a significance level of $1 \%$. The generalised Bonferroni method adjusts the significance level such that hypothesis $H_{0,(i)}, i=1, \ldots, s$, is deemed rejected if and only if:

$$
\hat{p}_{(i)} \leq \alpha_{(i)} \equiv k \cdot \alpha / s
$$

This procedure has the advantage of being robust to the dependence structure of the hypothesis tests.

\section{Empirical Results}

In Table 5, we present the results of our DCC-GARCH methodology. We clearly observe that both STZ and 5909.JP have had no correlation with Chinese financial markets. However, this is not the case for CML. Each company analysed had strong positive interactions with the DJIA, with STZ being the most positively related $(+0.7543)$ as it is an American company traded on the NYSE. However, without any direct exposure outside of un-diversifiable risk, all of the analysed companies exhibit strong negative hourly returns in the period after the announcement of the existence of the COVID-19 pandemic. Further, there is an exceptionally large significant increase in hourly volatility for each of the analysed companies. While in Figure 3, we observe the time-varying dynamic conditional correlations between each exposed company and the two key Chinese markets, the Shanghai and Shenzhen stock exchanges. In each case, after mitigating international effects, there is evidence of a sharp increase in dynamic correlations between the companies and Chinese markets with the exception of CML in South Africa. There is clear evidence that Constellation Brands (STZ) and Corona Corp (5909:JP) experienced a sharp and sustained deterioration in share prices outside of that expected through market-driven forces. The reasons for so would be deemed somewhat irrational, but mostly very unfortunately driven by name association. In general, all three considered companies have no interactions with hedging alternatives with two exceptions. 5909.JP has negative interactions with gold while CML has positive interactions with WTI. For robustness, a similar methodology was applied in Figure 4 for comparable companies such as Anheuser-Busch InBev SA/NV, Ambev SA and United Breweries Co. Inc. We observe that similar sharp elevations in dynamic correlations with both the Shanghai and Shenzhen stock exchanges are not observed.

The source of this unwarranted reputational damage can be identified through a number of social media memes linking the beer 'Corona' which is owned by Constellation Brands (STZ) and 
the coronavirus, known as the COVID-19 pandemic. The intention to buy Corona beer in the United States among adults has fallen to its lowest level in the past two years, while the perception of the brand has also collapsed. In a 27 February 2020 release, $5 \mathrm{~W}$ conducted phone surveys with 737 American beer drinkers, identifying that $38 \%$ of respondents would not buy Corona under any circumstances since the beginning of the coronavirus. Further, $16 \%$ of respondents stated confusion as to whether Corona beer was actually related to the coronavirus. A measure of how likely consumers are to buy the beer has fallen to a two-year low (according to YouGov, a market research firm). Corona's rating according to the firm had fallen to 51 from 75 at the start of the 2020, indicating a strong decline in sentiment towards the brand.

Further, the trading volumes in the investigated companies increased sharply during this time, indicating a potential role for $\mathrm{AI}$ and algorithmic trading strategies in the sharp decline in share price in line with the collapse of corporate sentiment. Overall, it is very much evident that companies such as STZ experienced a sharp and sustained deterioration on the fair valuation of their corporations during this time due to the unfortunate coincidence of sharing their names with an international pandemic.

\section{Concluding Comments}

There is a significant body of research, to which we add, which suggests that name and brand salience is an important pricing element for companies. We document negative knock-on effects from the coronavirus pandemic on some companies with related names, over and above the actual economic effects. While such companies have not in any way been connected or responsible for the COVID-19 outbreak, they appear to have unfortunately been the target of sustained reputational damage. The role of algorithmic trading cannot be ruled out, as evident in the elevated traded volumes during these times.

\section{References}

Akhtaruzzaman, M., A. Sensoy, and S. Corbet (2019). The influence of bitcoin on portfolio diversification and design. Finance Research Letters, 101344.

Akyildirim, E., S. Corbet, M. Efthymiou, C. Guiomard, J. O'Connell, and A. Sensoy (2020). The financial market effects of international aviation disasters. International Review of Financial Analysis 69.

Akyildirim, E., S. Corbet, P. Katsiampa, N. Kellard, and A. Sensoy (2019). The development of bitcoin futures: Exploring the interactions between cryptocurrency derivatives. Finance Research Letters.

Akyildirim, E., S. Corbet, B. Lucey, A. Sensoy, and L. Yarovaya (2019). The relationship between implied volatility and cryptocurrency returns. Finance Research Letters.

Baldwin, R. and B. W. di Mauro (2020). Economics in the Time of COVID-19. CEPR Press VoxEU. org. 
Benos, E. and M. Jochec (2013). Patriotic name bias and stock returns. Journal of Financial Markets 16(3), $550-570$.

Biktimirov, E. and F. Durrani (2017). Market reactions to corporate name changes: evidence from the toronto stock exchange. International Journal of Managerial Finance 13(1), 50-69.

Bollerslev, T. (1986). Generalized autoregressive conditional heteroskedasticity. Journal of Econometrics 31(3), 307-327.

Cooper, M., H. Gulen, and P. Raghavendra Rau (2005). Changing names with style: Mutual fund name changes and their effects on fund flows. Journal of Finance 60(6), 2825-2858.

Cooper, M., A. Khorana, I. Osobov, A. Patel, and P. Rau (2005). Managerial actions in response to a market downturn: Valuation effects of name changes in the dot.com decline. Journal of Corporate Finance 11(1-2), $319-335$.

Cooper, M. J., O. Dimitrov, and P. R. Rau (2001). A rose. com by any other name. The journal of Finance 56(6), 2371-2388.

Corbet, S., M. Dowling, and M. Cummins (2015). Analyst recommendations and volatility in a rising, falling, and crisis equity market. Finance Research Letters 15, 187-194.

Corbet, S., C. Larkin, B. Lucey, A. Meegan, and L. Yarovaya (2020). The impact of macroeconomic news on bitcoin returns. European Journal of Finance.

Corbet, S., C. Larkin, B. Lucey, and L. Yarovaya (2020). Kodakcoin: a blockchain revolution or exploiting a potential cryptocurrency bubble? Applied Economics Letters 27(7), 518-524.

Ekinci, C., E. Akyildirim, and S. Corbet (2019). Analysing the dynamic influence of us macroeconomic news releases on turkish stock markets. Finance Research Letters 31, 155-164.

Engle, R. (2002). Dynamic conditional correlation: A simple class of multivariate generalized autoregressive conditional heteroskedasticity models. Journal of Business $\&$ Economic Statistics 20(3), 339-350.

Goodell, J. W. (2020). Covid-19 and finance: Agendas for future research. Finance Research Letters, 101512.

Head, A., G. Smith, and J. Wilson (2009). Would a stock by any other ticker smell as sweet? The Quarterly Review of Economics and Finance 49(2), 551-561.

Jain, A. and C. Jain (2019). Blockchain hysteria: Adding "blockchain" to company's name. Economics Letters 181, 178-181.

Kadapakkam, P.-R. and L. Misra (2007). What's in a nickname? price and volume effects of a pure ticker symbol change. Journal of Financial Research 30(1), 53-71.

Kashmiri, S. and V. Mahajan (2014). A rose by any other name: Are family firms named after their founding families rewarded more for their new product introductions? Journal of Business Ethics 124(1), 81-99.

Katsiampa, P., S. Corbet, and B. Lucey (2019a). High frequency volatility co-movements in cryptocurrency markets. Journal of International Financial Markets, Institutions and Money 62, 35-52.

Katsiampa, P., S. Corbet, and B. Lucey (2019b). Volatility spillover effects in leading cryptocurrencies: A bekkmgarch analysis. Finance Research Letters 29, 68-74. 
Kot, H. (2011). Corporate name changes: Price reactions and long-run performance. Pacific Basin Finance Journal 19(2), 230-244.

Mase, B. (2009). The impact of name changes on company value. Managerial Finance 35(4), 316-324.

Sharif, A., C. Aloui, and L. Yarovaya (2020). Covid-19 pandemic, oil prices, stock market and policy uncertainty nexus in the us economy: Fresh evidence from the wavelet-based approach. Oil Prices, Stock Market and Policy Uncertainty Nexus in the US Economy: Fresh Evidence from the Wavelet-Based Approach (April 13, 2020).

Sharma, P., S. Paul, and S. Sharma (2020). What's in a name? a lot if it has "blockchain". Economics Letters 186, 108818.

Xing, X., R. I. Anderson, and Y. Hu (2016). What's a name worth? the impact of a likeable stock ticker symbol on firm value. Journal of Financial Markets 31, 63-80. 
Table 1: Key dates in the Chinese COVID-19 outbreak

\begin{tabular}{|c|c|}
\hline Date & Event \\
\hline December 31, 2019 & $\begin{array}{l}\text { Cases of pneumonia detected in Wuhan, China, are first re- } \\
\text { ported to the WHO. During this reported period, the virus is } \\
\text { unknown. The cases occur between December } 12 \text { and Decem- } \\
\text { ber } 29 \text {, according to Wuhan Municipal Health. }\end{array}$ \\
\hline January 1, 2020 & $\begin{array}{l}\text { Chinese health authorities close the Huanan Seafood Whole- } \\
\text { sale Market after it is discovered that wild animals sold there } \\
\text { may be the source of the virus. }\end{array}$ \\
\hline January 5, 2020 & $\begin{array}{l}\text { China announces that the unknown pneumonia cases in } \\
\text { Wuhan are not SARS or MERS }\end{array}$ \\
\hline January 7, 2020 & $\begin{array}{l}\text { Chinese authorities confirm that they have identified the virus } \\
\text { as a novel coronavirus, initially named } 2019-\mathrm{nCoV} \text { by the } \\
\text { WHO. }\end{array}$ \\
\hline January 11, 2020 & $\begin{array}{l}\text { The Wuhan Municipal Health Commission announces the first } \\
\text { death caused by the coronavirus. A } 61 \text {-year-old man, exposed } \\
\text { to the virus at the seafood market, died on January } 9 \text { after } \\
\text { respiratory failure caused by severe pneumonia. }\end{array}$ \\
\hline January 13, 2020 & $\begin{array}{l}\text { First cross-border transmission as Thai authorities report a } \\
\text { case of infection caused by the coronavirus. The infected in- } \\
\text { dividual is a Chinese national who had arrived from Wuhan. }\end{array}$ \\
\hline
\end{tabular}

Note: The above table consists of the key events relating to the Chinese epicentre COVID-19 outbreak. The dates represent dummy variables in the associated GARCH and DCC-GARCH estimations. 
Table 2: Selected companies under observation

\begin{tabular}{|c|c|c|c|}
\hline Name & Ticker & Exchange & Industry \\
\hline $\begin{array}{l}\text { Constellation } \\
\text { Brands Inc }\end{array}$ & STZ & $\begin{array}{l}\text { New York Stock } \\
\text { Exchange }\end{array}$ & $\begin{array}{l}\text { Fortune } 500 \text { company, is an international producer and } \\
\text { marketer of beer, wine and spirits. Constellation is } \\
\text { the largest beer import company in the US, measured } \\
\text { by sales, and has the third-largest market share of all } \\
\text { major beer suppliers. }\end{array}$ \\
\hline Corona Corp & 5909:JP & $\begin{array}{l}\text { Tokyo Stock Ex- } \\
\text { change }\end{array}$ & $\begin{array}{l}\text { Manufactures and sells air-conditioners, heaters, and } \\
\text { household equipment. The products include oil- } \\
\text { heating units, air purifiers, humidifiers, and water } \\
\text { heaters. }\end{array}$ \\
\hline $\begin{array}{l}\text { Coronation Fund } \\
\text { Managers Ltd }\end{array}$ & CML & $\begin{array}{l}\text { Johannesburg } \\
\text { Stock Exchange }\end{array}$ & $\begin{array}{l}\text { Coronation Fund Managers is a South-African third- } \\
\text { party fund management company, headquartered in } \\
\text { Cape Town. The company has locations in all South } \\
\text { African major centres and offices in, Ireland, United } \\
\text { Kingdom and in Namibia where it is represented by } \\
\text { Namibia Asset Management a strategic partner. }\end{array}$ \\
\hline
\end{tabular}

Note: The above companies represent a sample that possesses the term 'Corona' as a substantial component of the corporate brand. In the case of Constellation Brands Inc, the company owns the beer branded 'Corona'.

Table 3: Summary statistics of selected financial market variables

\begin{tabular}{|c|c|c|c|c|c|c|c|c|c|}
\hline \multicolumn{10}{|c|}{ Total Period Analysed (5701 observations) } \\
\hline & STZ & 5909:JP & CML & Shanghai & Shenzhen & DJIA & WTI & Gold & Bitcoin \\
\hline Mean & 0.0000 & 0.0000 & 0.0000 & 0.0000 & 0.0000 & 0.0000 & 0.0000 & 0.0000 & 0.0001 \\
\hline Std Dev & 0.0045 & 0.0035 & 0.0044 & 0.0023 & 0.0028 & 0.0023 & 0.0047 & 0.0018 & 0.0092 \\
\hline Minimum & -0.0537 & -0.0496 & -0.0755 & -0.0718 & -0.0750 & -0.0615 & -0.0666 & -0.0225 & -0.0886 \\
\hline Maximum & 0.0539 & 0.0429 & 0.0435 & 0.0252 & 0.0304 & 0.0295 & 0.0724 & 0.0175 & 0.0865 \\
\hline Variance & 0.0000 & 0.0000 & 0.0000 & 0.0000 & 0.0000 & 0.0000 & 0.0000 & 0.0000 & 0.0001 \\
\hline Skewness & -0.4122 & -0.4904 & -1.2390 & -5.9042 & -3.4336 & -4.3918 & -0.0317 & -0.6658 & -0.2070 \\
\hline Kurtosis & 27.9622 & 33.7866 & 32.4863 & 196.9949 & 113.1889 & 140.2742 & 35.0332 & 17.6908 & 8.9373 \\
\hline \multicolumn{10}{|c|}{ Before Coronavirus (4580 observations) } \\
\hline & STZ & 5909:JP & CML & Shanghai & Shenzhen & DJIA & WTI & Gold & Bitcoin \\
\hline Mean & 0.0000 & 0.0000 & 0.0000 & 0.0000 & 0.0000 & 0.0000 & 0.0000 & 0.0000 & 0.0001 \\
\hline Std Dev & 0.0041 & 0.0036 & 0.0043 & 0.0020 & 0.0025 & 0.0016 & 0.0039 & 0.0016 & 0.0097 \\
\hline Minimum & -0.0537 & -0.0496 & -0.0755 & -0.0337 & -0.0371 & -0.0189 & -0.0410 & -0.0225 & -0.0886 \\
\hline Maximum & 0.0539 & 0.0429 & 0.0435 & 0.0252 & 0.0304 & 0.0175 & 0.0337 & 0.0138 & 0.0865 \\
\hline Variance & 0.0000 & 0.0000 & 0.0000 & 0.0000 & 0.0000 & 0.0000 & 0.0000 & 0.0000 & 0.0001 \\
\hline Skewness & -0.1666 & -0.5357 & -0.9621 & -0.5488 & -0.2841 & -1.0825 & -0.5360 & -0.4233 & -0.2010 \\
\hline Kurtosis & 34.1575 & 34.1932 & 33.7251 & 41.2553 & 33.4127 & 34.5759 & 10.4541 & 16.9029 & 8.3757 \\
\hline \multicolumn{10}{|c|}{ After Coronavirus (1122 observations) } \\
\hline & STZ & 5909:JP & CML & Shanghai & Shenzhen & DJIA & WTI & Gold & Bitcoin \\
\hline Mean & -0.0001 & -0.0001 & 0.0000 & 0.0000 & 0.0001 & -0.0001 & -0.0002 & 0.0000 & 0.0002 \\
\hline Std Dev & 0.0060 & 0.0030 & 0.0049 & 0.0031 & 0.0037 & 0.0040 & 0.0072 & 0.0022 & 0.0067 \\
\hline Minimum & -0.0511 & -0.0228 & -0.0588 & -0.0718 & -0.0750 & -0.0615 & -0.0666 & -0.0209 & -0.0530 \\
\hline Maximum & 0.0402 & 0.0294 & 0.0294 & 0.0129 & 0.0248 & 0.0295 & 0.0724 & 0.0175 & 0.0428 \\
\hline Variance & 0.0000 & 0.0000 & 0.0000 & 0.0000 & 0.0000 & 0.0000 & 0.0001 & 0.0000 & 0.0000 \\
\hline Skewness & -0.6542 & -0.1889 & -1.9568 & -11.6273 & -6.9313 & -3.8890 & 0.3583 & -0.9857 & -0.1866 \\
\hline Kurtosis & 15.3899 & 25.5440 & 27.9893 & 271.3470 & 151.0273 & 72.4226 & 28.6361 & 14.7752 & 7.6318 \\
\hline
\end{tabular}

Note: Hourly data is presented to the period 11 March 2019 and 10 March 2020, where the period denoted as both preand post-COVID-19 pandemic is denoted to be before and after 31 December 2019. 
Table 4: Correlations between identified companies and traditional financial markets, both before and after the COVID-19 outbreak

\begin{tabular}{|c|c|c|c|c|c|c|c|c|c|c|c|c|c|c|c|}
\hline \multicolumn{16}{|c|}{ Constellation Brands Inc } \\
\hline \multicolumn{8}{|c|}{ Before COVID-19 } & \multicolumn{8}{|c|}{ After COVID-19 } \\
\hline & Constell. & Shang. & Shenz. & DJIA & WTI & Gold & BTC & & Constell. & Shang. & Shenz. & DJIA & WTI & Gold & $\mathrm{BTC}$ \\
\hline Constell. & 1.000 & & & & & & & Constell. & 1.000 & & & & & & \\
\hline Shang. & 0.032 & 1.000 & & & & & & Shang. & 0.286 & 1.000 & & & & & \\
\hline Shenz. & 0.025 & 0.889 & 1.0000 & & & & & Shenz. & 0.315 & 0.967 & 1.000 & & & & \\
\hline DJIA & 0.394 & 0.165 & 0.1454 & 1.000 & & & & DJIA & 0.813 & 0.243 & 0.263 & 1.000 & & & \\
\hline WTI & 0.098 & 0.091 & 0.0802 & 0.302 & 1.000 & & & WTI & 0.552 & 0.484 & 0.488 & 0.601 & 1.000 & & \\
\hline Gold & -0.065 & -0.009 & -0.0141 & -0.180 & 0.013 & 1.000 & & Gold & 0.285 & 0.335 & 0.347 & -0.116 & 0.014 & 1.000 & \\
\hline $\mathrm{BTC}$ & 0.012 & 0.0188 & 0.020 & 0.036 & -0.007 & 0.039 & 1.000 & BTC & 0.650 & 0.343 & 0.385 & 0.429 & 0.279 & 0.468 & 1.000 \\
\hline \multicolumn{16}{|c|}{ Corona Corp } \\
\hline \multicolumn{7}{|c|}{ Before COVID-19 } & & \multicolumn{8}{|c|}{ After COVID-19 } \\
\hline & Cor C. & Shang. & Shenz. & DJIA & WTI & Gold & BTC & & Cor C. & Shang. & Shenz. & DJIA & WTI & Gold & BTC \\
\hline Cor C. & 1.000 & & & & & & & Cor C. & 1.00 & & & & & & \\
\hline Shang. & 0.106 & 1.000 & & & & & & Shang. & 0.502 & 1.000 & & & & & \\
\hline Shenz. & 0.097 & 0.889 & 1.000 & & & & & Shenz. & 0.517 & 0.967 & 1.000 & & & & \\
\hline DJIA & 0.082 & 0.145 & 0.145 & 1.000 & & & & DJIA & 0.263 & 0.243 & 0.263 & 1.000 & & & \\
\hline WTI & 0.000 & 0.091 & 0.080 & 0.302 & 1.000 & & & WTI & 0.363 & 0.484 & 0.488 & 0.601 & 1.000 & & \\
\hline Gold & -0.058 & -0.009 & -0.014 & -0.182 & 0.013 & 1.000 & & Gold & 0.334 & 0.335 & 0.347 & -0.116 & 0.014 & 1.000 & \\
\hline BTC & -0.032 & 0.018 & 0.020 & 0.036 & -0.007 & 0.039 & 1.000 & BTC & 0.363 & 0.343 & 0.385 & 0.429 & 0.279 & 0.468 & 1.000 \\
\hline \multicolumn{16}{|c|}{ Coronation Fund Managers Ltd } \\
\hline \multicolumn{7}{|c|}{ Before COVID-19 } & \multicolumn{9}{|c|}{ After COVID-19 } \\
\hline & CFM & Shang. & Shenz. & DJIA & WTI & Gold & BTC & & CFM & Shang. & Shenz. & DJIA & WTI & Gold & BTC \\
\hline CFM & 1.000 & & & & & & & CFM & 1.000 & & & & & & \\
\hline Shang. & 0.155 & 1.000 & & & & & & Shang. & 0.383 & 1.000 & & & & & \\
\hline Shenz. & 0.126 & 0.889 & 1.000 & & & & & Shenz. & 0.365 & 0.967 & 1.000 & & & & \\
\hline DJIA & 0.159 & 0.165 & 0.145 & 1.000 & & & & DJIA & 0.702 & 0.243 & 0.263 & 1.000 & & & \\
\hline WTI & 0.145 & 0.091 & 0.080 & 0.302 & 1.000 & & & WTI & 0.611 & 0.484 & 0.488 & 0.601 & 1.000 & & \\
\hline Gold & -0.062 & -0.009 & -0.014 & -0.180 & 0.013 & 1.000 & & Gold & 0.293 & 0.335 & 0.347 & -0.116 & 0.014 & 1.000 & \\
\hline BTC & 0.044 & 0.018 & 0.020 & 0.036 & -0.007 & 0.039 & 1.000 & BTC & 0.516 & 0.343 & 0.385 & 0.429 & 0.279 & 0.468 & 1.000 \\
\hline
\end{tabular}

Note: In the above table, the changing correlations between the identified companies susceptible to the 'corona' naming shock and these financial assets. The date indicating the start of the pandemic is that of 31 December 2019, when cases of pneumonia detected in Wuhan, China, are first reported to the WHO. 
Table 5: DCC-GARCH estimates

\begin{tabular}{|c|c|c|c|}
\hline Dependent Variable & Constellation B. & Corona C. & Coronation F.M. \\
\hline 1st lag & $\begin{array}{c}0.0863^{* * *} \\
(0.0253)\end{array}$ & $\begin{array}{c}-0.0306 \\
(0.0270)\end{array}$ & $\begin{array}{c}0.0013^{* *} \\
(0.0450)\end{array}$ \\
\hline 2nd lag & $\begin{array}{c}0.0847^{* *} * \\
(0.0394)\end{array}$ & $\begin{array}{c}-0.0663^{*} \\
(0.0384)\end{array}$ & $\begin{array}{l}-0.0155 \\
(0.0390)\end{array}$ \\
\hline 3rd lag & $\begin{array}{c}0.0052 \\
(0.0463)\end{array}$ & $\begin{array}{l}-0.0076 \\
(0.0372)\end{array}$ & $\begin{array}{c}-0.0002^{* * * *} \\
(0.0411)\end{array}$ \\
\hline Shanghai SE & $\begin{array}{c}0.0472 \\
(0.1062)\end{array}$ & $\begin{array}{c}0.0499 \\
(0.0665)\end{array}$ & $\begin{array}{c}0.3666^{* * * *} \\
(0.1355)\end{array}$ \\
\hline Shenzhen SE & $\begin{array}{c}0.0190 \\
(0.0863)\end{array}$ & $\begin{array}{c}0.0429 \\
(0.0516)\end{array}$ & $\begin{array}{c}-0.1959^{*} \\
(0.1173)\end{array}$ \\
\hline DJIA & $\begin{array}{c}0.7543^{* * *} \\
(0.0708)\end{array}$ & $\begin{array}{c}0.1303^{* * *} \\
(0.0361)\end{array}$ & $\begin{array}{c}0.3213^{* * *} \\
(0.0947)\end{array}$ \\
\hline WTI & $\begin{array}{c}0.0111 \\
(0.0258)\end{array}$ & $\begin{array}{l}-0.0177 \\
(0.0140)\end{array}$ & $\begin{array}{c}0.0861^{* *} \\
(0.0359)\end{array}$ \\
\hline Gold & $\begin{array}{c}0.0517 \\
(0.0723)\end{array}$ & $\begin{array}{c}-0.1317^{* * *} \\
(0.0417)\end{array}$ & $\begin{array}{c}0.0004 \\
(0.0894)\end{array}$ \\
\hline Bitcoin & $\begin{array}{c}0.0042 \\
(0.0092)\end{array}$ & $\begin{array}{c}0.0019 \\
(0.0081)\end{array}$ & $\begin{array}{c}0.0188 \\
(0.0174)\end{array}$ \\
\hline COVID-19, Mean eq. & $\begin{array}{c}-0.0016^{* * *} \\
(0.0003)\end{array}$ & $\begin{array}{c}-0.0011^{* * *} \\
(0.0004)\end{array}$ & $\begin{array}{c}-0.0008^{* * *} \\
(0.0001)\end{array}$ \\
\hline Constant & $\begin{array}{c}0.0003^{* * *} \\
(0.0001)\end{array}$ & $\begin{array}{c}0.0023^{* * *} \\
(0.0004)\end{array}$ & $\begin{array}{c}0.0002^{* * *} \\
(0.0001)\end{array}$ \\
\hline COVID-19, Var eq. & $\begin{array}{c}0.0056^{* * *} \\
(0.0000)\end{array}$ & $\begin{array}{l}0.0016^{*} \\
(0.0000)\end{array}$ & $\begin{array}{c}0.0012^{* * *} \\
(0.0000)\end{array}$ \\
\hline $\mathrm{ARCH}$ & $\begin{array}{c}0.0240^{* * *} \\
(0.0070)\end{array}$ & $\begin{array}{c}0.0760 * * \\
(0.0309)\end{array}$ & $\begin{array}{c}0.0993^{*} \\
(0.0517)\end{array}$ \\
\hline GARCH & $\begin{array}{c}0.8619^{* * *} \\
(0.0694)\end{array}$ & $\begin{array}{c}0.8596^{* * *} \\
(0.0692)\end{array}$ & $\begin{array}{c}0.7763^{* * *} \\
(0.2269)\end{array}$ \\
\hline Log likelihood & 1719.07 & 3823.18 & 1518.22 \\
\hline Wald chi2(10) & 194.72 & 60.20 & 60.32 \\
\hline Prob $>$ chi2 & 0.0000 & 0.0000 & 0.0000 \\
\hline
\end{tabular}

Note: The presented analysis was conducted using hourly data between the period 11 March 2019 and 10 March 2020 (5,701 observations), where the period denoted as both pre- and post-COVID-19 pandemic (4,580 and 1,122 observations respectively) is denoted to be before and after 31 December 2019.. ***, ** and * indicates statistical significance at the $1 \%, 5 \%$ and $10 \%$ levels respectively. 
Figure 1: Price and volatility behaviour of the selected companies

a) Constellation Brands Inc (Ticker: STZ)

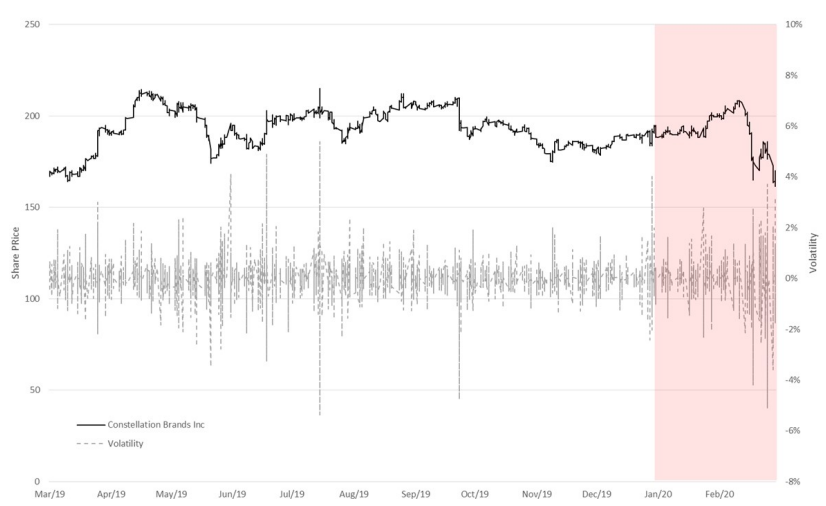

b) Corona Corp (Ticker: 5909:JP)

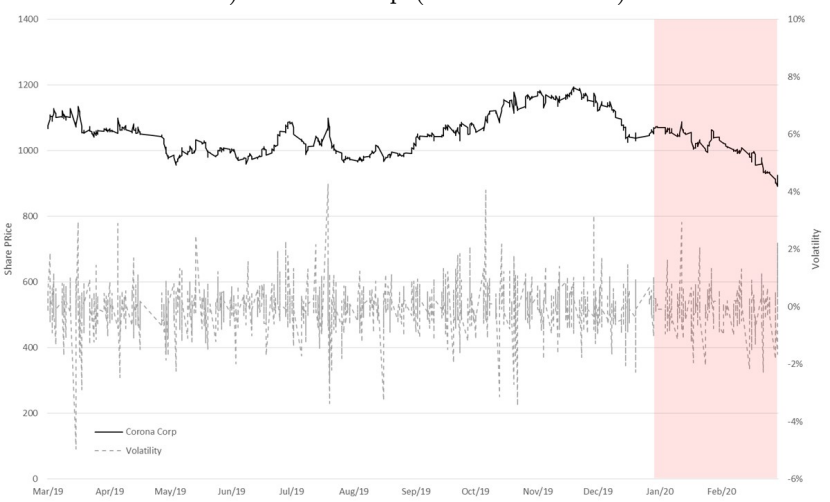

c) Coronation Fund Managers Ltd (Ticker: CML)

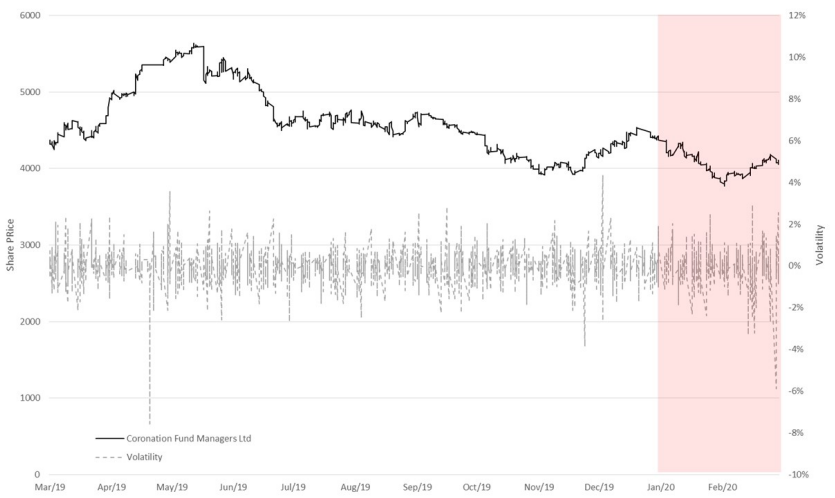

Note: The above figure represents the price (left-hand axis) and volatility (right-hand axis) behaviour of the selected companies. The shaded area to the right represents the period inclusive of the outbreak of the COVID-19 pandemic. 
Figure 2: Total number of announced COVID-19 cases worldwide
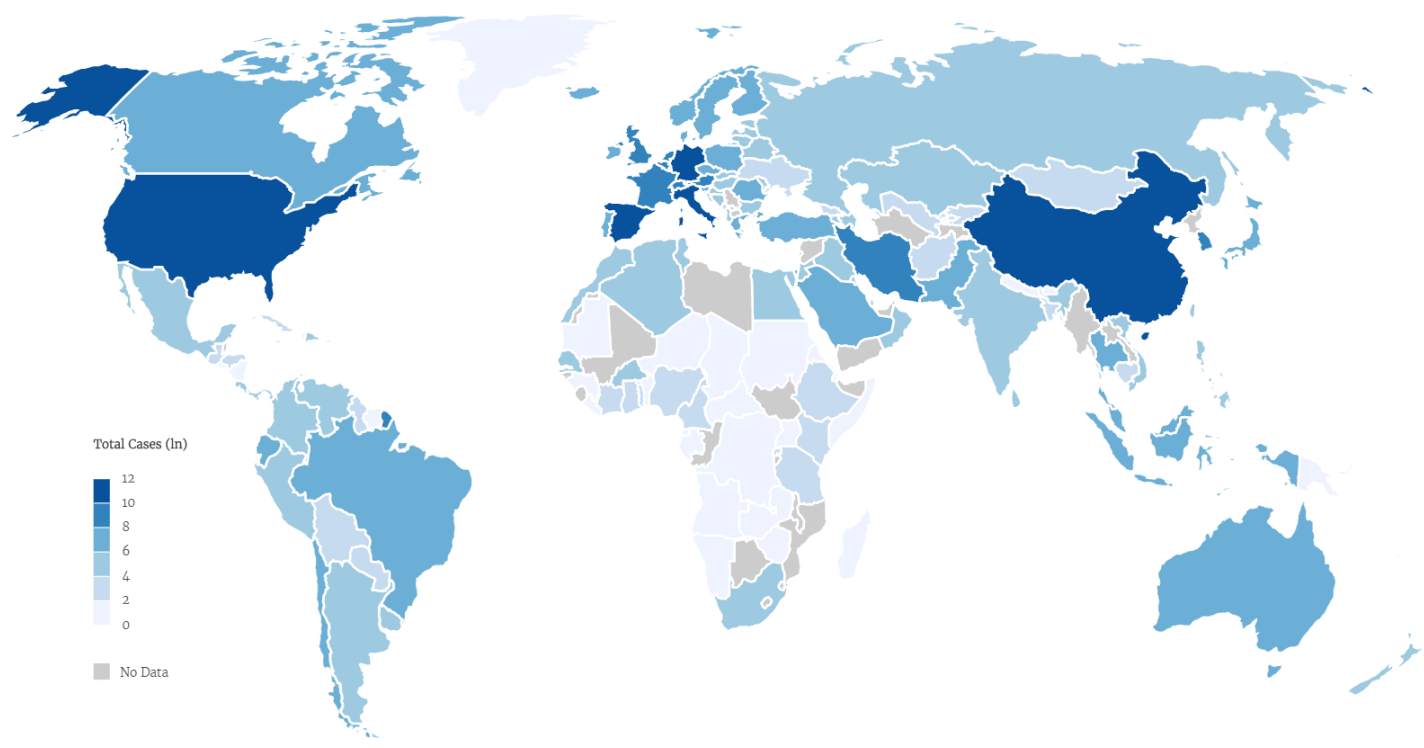

Note: The above figure represents the log of total calculated cases as of 27 February 2020 during the outbreak of the COVID-19 pandemic. Data is sourced from WHO estimates as available through Thomson Reuters Eikon. 
Figure 3: Dynamic correlations between denoted company and the Shanghai \& Shenzhen Stock Exchanges a) Constellation Brands Inc (Ticker: STZ)

i) Shanghai

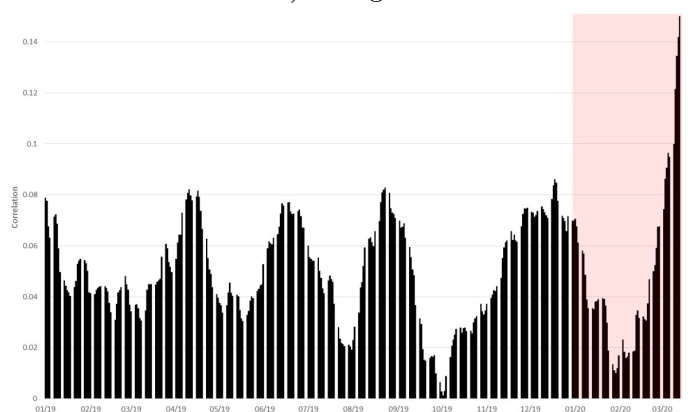

b) Corona Corp (Ticker: 5909:JP)

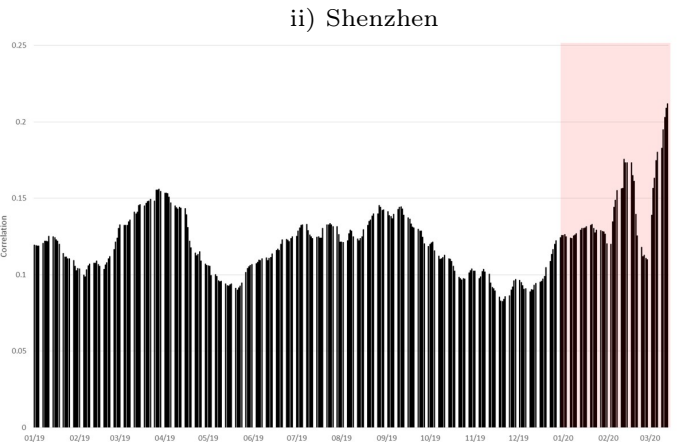

i) Shanghai

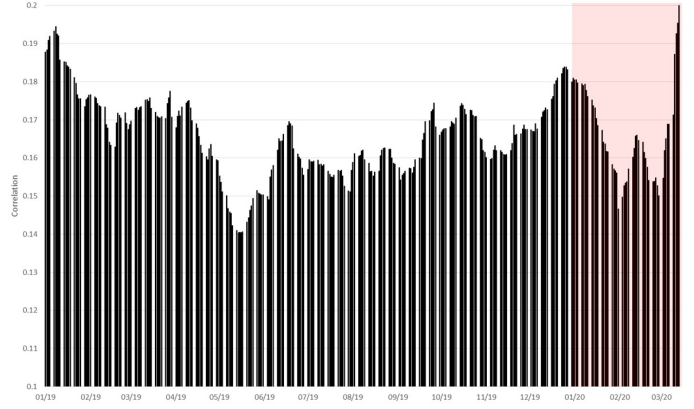

c) Coronation Fund Managers Ltd (Ticker: CML)

i) Shanghai

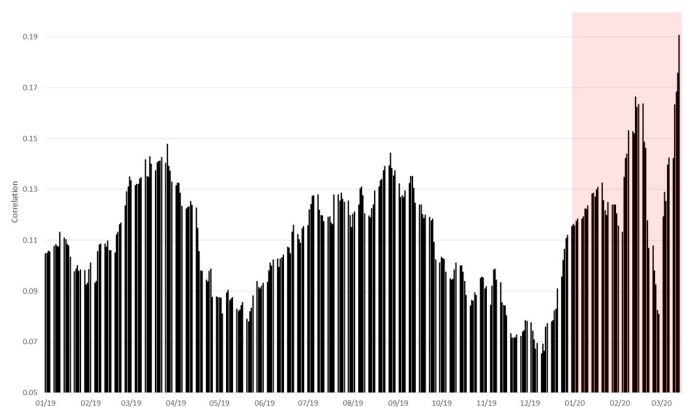

ii) Shenzhen

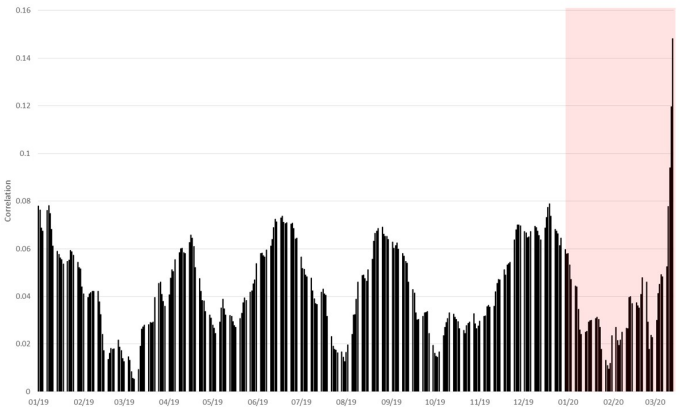

ii) Shenzhen

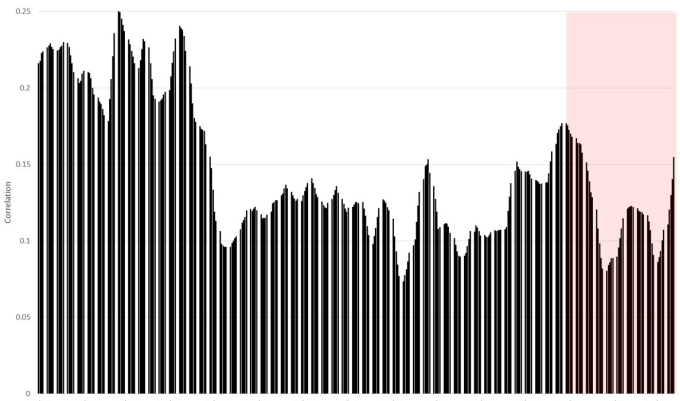

Note: The above figure represents the estimated dynamic correlations between the selected companies and the Chinese stock exchange. The selected time periods presented no similar increases and decreases in correlation with domestic indices, indicated significant behavioural shift. 
Figure 4: Dynamic correlations between non-Corona related companies and the Shanghai \& Shenzhen Stock Exchanges

a) Anheuser-Busch InBev SA/NV:

i) Shanghai

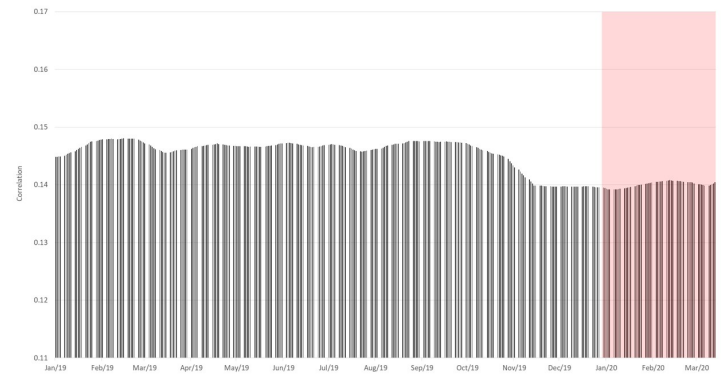

ii) Shenzhen

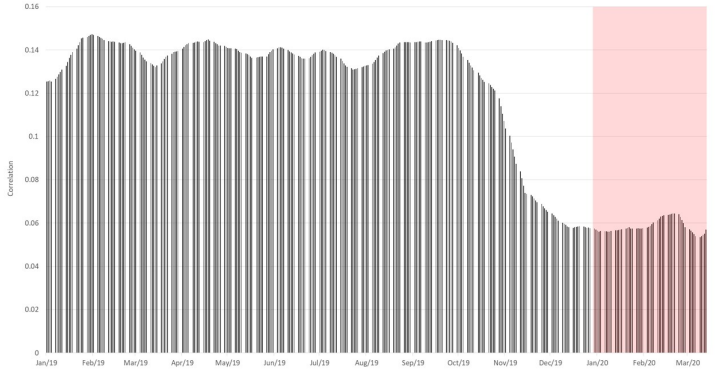

b) Ambev SA

i) Shanghai

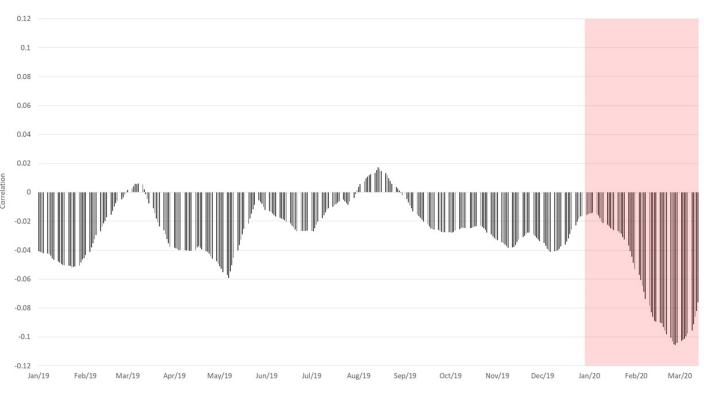

ii) Shenzhen

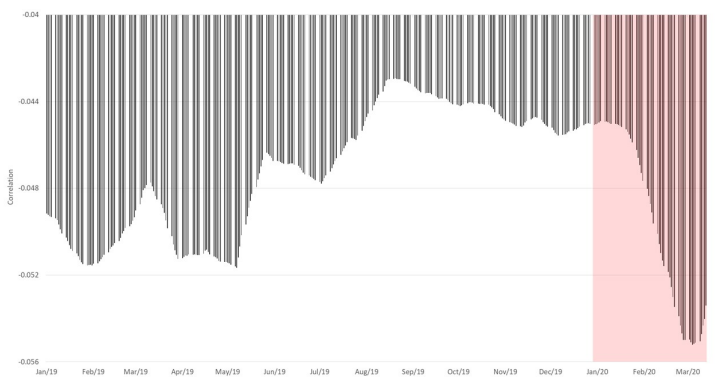

c) United Breweries Co. Inc.

i) Shanghai

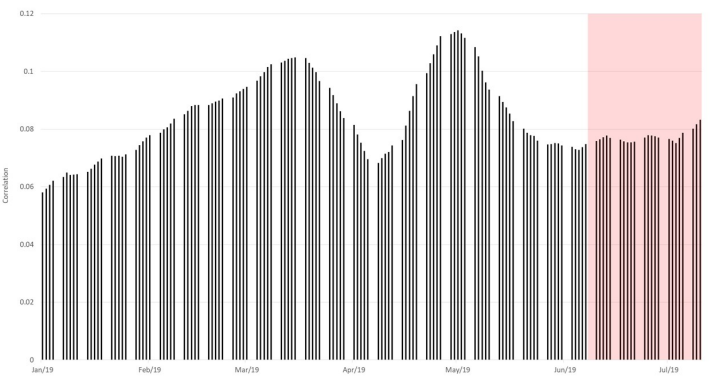

ii) Shenzhen

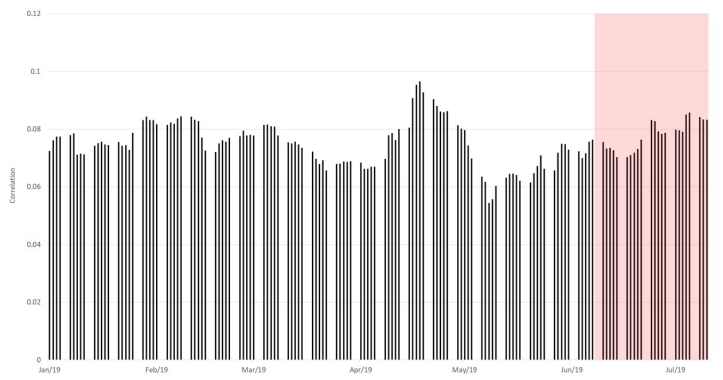

Note: The above figure represents the estimated dynamic correlations between the selected non-Corona named companies and the Chinese stock exchange as a robustness test of the provided results. 